\title{
Reproduction reduces HSP70 expression capacity in Argopecten purpuratus scallops subject to hypoxia and heat stress
}

\author{
Katherina Brokordt* , Hernán Pérez, Catalina Herrera, Alvaro Gallardo \\ Centro de Estudios Avanzados en Zonas Áridas (CEAZA), Universidad Católica del Norte, Larrondo 1281, Coquimbo, Chile
}

\begin{abstract}
In scallops, gonad production is highly demanding energetically, and reproduction usually occurs during spring-summer, a period of strong environmental changes. The synthesis of heat-shock proteins (HSPs) is a major mechanism of stress tolerance in animals, including scallops, and HSP expression contributes considerably to cellular energy demand. Therefore, reproductive investment may limit the availability of energy (in terms of ATP) for the expression of HSP in organisms exposed to environmental stress. We evaluated the stress response capacity of adult Argopecten purpuratus scallops to high temperature and hypoxia. Stress response capacity was assessed through gene expression (for temperature stress) and protein induction of $70 \mathrm{kD}$ HSP at 3 reproductive stages: immature, mature and spawned. We also evaluated the effect of reproductive status on the cellular ATP provisioning capacity through citrate synthase activity. Immature scallops exposed to thermal stress showed 1.3- and 1.5-fold increases in hsp70 mRNA and HSP70 protein levels, respectively, and those exposed to hypoxia doubled their level of HSP70 compared to non-stressed immature scallops. However, following gonad maturation and spawning, hsp 70 mRNA increased by only 0.49 - and 0.65 -fold, respectively, after thermal stress and HSP70 protein levels of scallops exposed to thermal and hypoxia stressors did not differ from those of nonstressed animals. In parallel, citrate synthase showed its highest level in immature scallops, declined with gonad maturation, and was lowest in spawned scallops. These results suggest that reproductive investment reduces the stress response capacity of $A$. purpuratus and that mature and spawned scallops could be more vulnerable to environmental stressors than immature individuals.
\end{abstract}

KEY WORDS: Reproductive cost $\cdot$ HSP70 $\cdot$ hsp70 mRNA - Stress response - Thermal stress · Hypoxia stress $\cdot$ Scallops $\cdot$ Argopecten purpuratus

\section{INTRODUCTION}

In most organisms, reproduction requires high levels of energy investment. The amount of energy invested and the stage during which this energy is needed depend, in part, on the organism's reproductive strategy. In broadcast-spawning mollusks such as scallops, the majority of energy investment into gamete production occurs during gonad maturation (Sastry 1968, Barber \& Blake 1983, Martínez 1991). In

\footnotetext{
*Corresponding author: kbrokord@ucn.cl
}

scallops, this process occurs even when food is limited, and as much as $50 \%$ of the energy reserves stored in somatic tissues can be mobilized to support reproductive maturation (Martínez \& Mettifogo 1998, Lodeiros et al. 2001, Brokordt \& Guderley 2004). The mobilization of energy reserves and re-channeling of consumed energy to support gonad maturation limit the amount of energy available or decrease the metabolic capacity to support other vital processes. For example, in mollusks, reproductive investment has

() The authors 2015. Open Access under Creative Commons by Attribution Licence. Use, distribution and reproduction are unrestricted. Authors and original publication must be credited. 
been shown to decrease the amount of energy available for growth (Iglesias \& Navarro 1991), increase maintenance metabolic demands (Kraffe et al. 2008), decrease aerobic metabolic capacity (Brokordt et al. 2000a,b) and decrease swimming ability and escape response capacity (Brokordt et al. 2000a,b, 2003, 2006, Kraffe et al. 2008). Additionally, in several bivalve species (e.g. mussels, scallops and oysters), periods of reproductive activity and mass mortality have been observed to coincide (Tremblay et al. 1998, Xiao et al. 2005, Samain et al. 2007), possibly due to the presence of several stressful environmental factors. In several bivalve species, reproductive maturation occurs during the spring-summer season, characterized by strong environmental fluctuations in conditions such as temperature and oxygen level (Cheney et al. 2000, Tomaru et al. 2001, Cabello et al. 2002, Xiao et al. 2005, Li et al. 2007, Zhang et al. 2010).

When environmental conditions exceed an organism's ability to adapt physiologically, this produces physiological stress. Organisms have evolved several physiological responses to tolerate environmental stress. Among cellular stress responses, one of the most important is the production of stress proteins, commonly known as heat-shock proteins (HSPs) (Morris et al. 2013). HSPs are present in all organisms; they are among the most abundant soluble proteins in the body and are induced by most stressors (Calderwood 2007). HSPs are molecular chaperones that decrease the aggregation of unfolded proteins, assist in protein refolding, and facilitate the channeling of irreversibly denatured proteins towards proteolytic degradation (Parsell \& Lindquist 1993). Among the HSPs, the HSP70 family (so denoted due to its $70 \mathrm{kD}$ mass) is the most abundant, and, in many organisms, is considered the most important (Feder \& Hofmann 1999, Sørensen 2010). HSP70 activity augments tolerance to several stressful conditions, including extreme temperature, hypoxia, UV radiation, and the presence of toxins; it also participates in the immune response (reviewed by Feder \& Hofmann 1999, Calderwood 2007). Under 'non-stress' conditions, HSPs also play an important role in protein biogenesis by preventing the premature folding and aggregation of emerging polypeptides (Frydman et al. 1994, Hartl \& HayerHartl 2002). Therefore, HSPs not only increase the organism's capacity to tolerate stress conditions but also enhance the efficiency of protein synthesis. However, gene expression and protein synthesis processes, as well as the chaperoning activity of these proteins, generate high cellular demands for energy in terms of ATP (Hofmann \& Somero 1995, Somero 2002, Sharma et al. 2010). Therefore, we propose that upon exposure to a stress factor, the observed level of induced HSP70 may reflect not only the level of molecular damage, but also the capacity to express this protein, which could be energetically limited or affected by the physiological status of the animals. There is some evidence that supports this idea; for example, a study made in blood cells from rainbow trout showed that the in vitro inhibition of energetic metabolic pathways decreased ATP by $79 \%$, and this reduced hsp 70 mRNA levels after heat shock (Currie et al. 1999). Also, Mizrahi et al. (2011) observed a negative correlation between endogenous levels of the HSP70 isoform of the foot tissue and albumen gland mass (larger albumen glands indicative of more mature animals) of land snails (Shincterochila cariosa and $S$. zonata). Finally, we have recently shown that the marine snail Concholepas concholepas under reduced nutritional status showed lower levels of HSP70 induction upon exposure to stress factors during low tide compared with snails in good nutritional status (Jeno \& Brokordt 2014).

As both reproduction and the synthesis of stress proteins are energetically expensive, there could be an energetic compromise between these 2 processes. We hypothesized that reproductive investment may limit the availability of energy (in terms of ATP) for HSP70 expression in organisms exposed to environmental stress. To test this hypothesis, we compared the hsp70 mRNA levels and HSP70 abundance among Argopecten purpuratus scallops at different reproductive stages (immature, mature and spawned) exposed to 2 different stress factors (hypoxia and high temperature). Hsp70 mRNA levels were measured only upon exposure to thermal stress. In parallel, we evaluated the effect of reproductive status on the aerobic metabolic capacity of these scallops, measured through citrate synthase (CS) enzymatic activity. Through the activity of this key enzyme we aimed to assess the effect of reproduction upon one of the main ATP provisioning metabolic pathways. We used A. purpuratus as a model because as a broadcast spawner this species has previously been shown to have high reproductive investment (Martínez 1991, Martínez \& Mettifogo 1998, Martínez et al. 2000). Also, most natural beds and cultures of $A$. purpuratus are located in bays near upwelling zones and are thus exposed to frequent environmental changes, especially during the reproductive period (Zhang et al. 2010, CEAZA Oceanographic Monitoring System unpubl. data). 


\section{MATERIALS AND METHODS}

\section{Animal procurement and holding conditions}

Adult Argopecten purpuratus (70-80 $\mathrm{mm}$ shell height) with immature $(\mathrm{n}=60)$ and mature $(\mathrm{n}=120)$ gonads were obtained from aquaculture centers located in Coquimbo, northern Chile $\left(30^{\circ} 16^{\prime} \mathrm{S}\right.$, $71^{\circ} 35^{\prime} \mathrm{W}$ ), during summer 2011. Summer is the most active reproductive season for $A$. purpuratus at Coquimbo, and because reproduction in this species is somewhat asynchronous (Cantillanez et al. 2005), it was possible to find animals at different stages of maturation. Reproductive stage was initially determined using a visual scale following Disalvo et al. (1984) and Martínez \& Pérez (2003), where immature individuals show flaccid and pale gonads, and mature individuals show intensely coloured, turgid gonads. In the case of spawned scallops, individuals were chosen from animals that were induced to spawn and subsequently showed empty gonads. Visual observations were thereafter verified via gonad mass measurements, as described below. The scallops were transported to the Universidad Católica del Norte's laboratory in Coquimbo. In order to reduce stress arising from the transport process, individuals were acclimated to laboratory conditions for $4 \mathrm{~d}$ in $1000 \mathrm{l}$ tanks supplied with filtered, aerated, running seawater $\left(\sim 18^{\circ} \mathrm{C}\right)$ and fed a diet of $50 \%$ Isochrysis galbana and $50 \%$ Chaetoceros calcitrans. Following acclimation, 60 mature scallops were stimulated to spawn by adding excess microalgae.

\section{Experimental design}

We first performed the thermal stress trial. Fifteen scallops from each reproductive stage (immature, mature and spawned) were subjected to a rapid temperature increase from 18 to $24^{\circ} \mathrm{C}$ and then maintained at $24^{\circ} \mathrm{C}$ for $6 \mathrm{~h}$. This increase of temperature was previously tested in a preliminary experiment to ensure a significant stress response in the scallops. An additional 15 scallops from each reproductive stage were maintained at baseline temperature $\left(18^{\circ} \mathrm{C}\right)$ over the same $6 \mathrm{~h}$ and served as controls (i.e. unstressed scallops).

For the hypoxia stress trial, 15 scallops from each reproductive stage were subjected to a rapid decrease in seawater oxygen content from saturation levels ( 8.0 $\mathrm{mg} \mathrm{O}_{2} \mathrm{l}^{-1}$ ) to hypoxic conditions (2.0$1.5 \mathrm{mg} \mathrm{O}_{2} \mathrm{l}^{-1}$ ) by adding gaseous nitrogen. Scallops were maintained under this hypoxic condition for $6 \mathrm{~h}$.
As controls (i.e. unstressed scallops), an additional 15 scallops from each reproductive stage were maintained under baseline oxygen conditions over the same $6 \mathrm{~h}$. During this trial, scallops were maintained at $18^{\circ} \mathrm{C}$.

Hypoxia treatments were based upon the oxygen fluctuations measured in Tongoy Bay during the spring-summer season by the CEAZA Oceanographic Monitoring System. Therefore, both the hypoxia level (2.0-1.5 $\left.\mathrm{mg} \mathrm{O}_{2} \mathrm{l}^{-1}\right)$ and the duration of the hypoxia cycles followed real environmental conditions to which the scallops are exposed.

Following each experiment, individuals were measured and their gonads were dissected and weighed. Each individual's gills were then extracted, deep frozen in liquid nitrogen and stored at $-80^{\circ} \mathrm{C}$ for later HSP70 quantification and CS enzymatic activity determination. Gill tissues from each scallop exposed to thermal stress trials were stored in RNAlater (Ambion) at $-20^{\circ} \mathrm{C}$ until processing for hsp 70 gene transcription determination.

In preliminary assays, we evaluated HSP70 levels after stress exposure in different tissues: muscle, mantle and gills. We did not measure HSP70 in gonads or digestive glands because these are very unstable tissues, i.e. they experience large changes in short time periods associated with reproductive status or food availability, respectively. The preliminary assays showed that after stress, HSP70 levels increased 1.5 times in muscle tissue, 2.0 times in mantle tissue and 3 times in gill tissue, compared with their respective control tissue from unstressed scallops. Based on these results, we performed the complete study in the gill tissue, which represents a large proportion of the scallops' soft tissues. Because we were looking for the association between HSP70 induction capacity and energetic metabolism capacity, CS was also measured in gill tissue.

\section{Total RNA extraction, cDNA synthesis and mRNA transcription analysis with quantitative real-time PCR}

Total RNA was isolated from the gill tissues using Trizol reagent (Invitrogen) according to the manufacturer's instructions. RQ1 RNase-Free DNase (Promega) was used to eliminate DNA contamination. Equal amounts of RNA from 3 individuals per treatment were pooled (thus the 15 individuals per treatment became $n=5$ per treatment). Each RNA pool was reverse transcribed using the Revertid H Minus First Strand cDNA Synthesis Kit (Fermentas) according to 
the manufacturer's instructions. We used $200 \mathrm{ng}$ of total RNA for the real-time PCR analysis. Hsp70 gene transcription was performed using specific $A$. purpuratus primers (hsp70F 5'GAG GCC GTCGCC TAT GGT GC3'; hsp70R 5'GCG GTC TCG ATA-CCC AGG GAC A3') (GenBank accession number FJ839890), for which PCR efficiency was previously verified through the standard curve method. The designed primers were selected from a conserved region that does not discriminate between genes encoding for different hsp70 isoforms and thus between constitutive and inducible ones. However, in preliminary studies using these primers, $h s p 70$ mRNA showed a strong increase after stress, which indicates that we are measuring the hsp70 inducible isoforms.

All real-time PCR reactions were performed in triplicate in a $20 \mu \mathrm{l}$ reaction mixture containing $5 \mu \mathrm{l}$ cDNA, $0.2 \mathrm{mM}$ of each primer, SYBR Green qPCR master mix 2X (Fermentas) and $50 \mathrm{nM}$ RoX solution. Real-time PCR reactions were run in a StepOne Plus Real-Time PCR System (Applied Biosystems) using the comparative $\Delta \Delta C_{\mathrm{T}}$ method (Livak \& Schmittgen 2001) and EF1 $\alpha$ (GenBank accession number ES469321.1) as an endogen control. In preliminary studies, the stability of this endogenous gene was tested for our species and tissues. Initial denaturing time was $10 \mathrm{~min}$ at $95^{\circ} \mathrm{C}$, followed by 40 cycles of denaturing at $95^{\circ} \mathrm{C}$ for $30 \mathrm{~s}$, annealing at $60^{\circ} \mathrm{C}$ for $30 \mathrm{~s}$, and extension at $72^{\circ} \mathrm{C}$ for $30 \mathrm{~s}$, with a ramp rate of the melt curve of $95^{\circ} \mathrm{C}(15 \mathrm{~s})$, $55^{\circ} \mathrm{C}(15 \mathrm{~s})$ and $95^{\circ} \mathrm{C}(15 \mathrm{~s})$.

\section{Extraction and quantification of total protein for HSP70 determination}

Total protein was quantified for $0.03 \mathrm{~g}$ of gill from each individual. Gill tissue was homogenized in $150 \mu \mathrm{l}$ of homogenization buffer $(32 \mathrm{mM}$ Tris- $\mathrm{HCl}$ at $\mathrm{pH} 7.5$, $2 \%$ SDS, 1 mM EDTA, 1 mM Pefabloc and $1 \mathrm{mM}$ protease inhibitor cocktail). The homogenate was incubated for $5 \mathrm{~min}$ at $100^{\circ} \mathrm{C}$, then resuspended in $100 \mu \mathrm{l}$ of homogenization buffer and re-incubated at $100^{\circ} \mathrm{C}$ for $5 \mathrm{~min}$. The homogenate was centrifuged at $10600 \times \mathrm{g}$ for $20 \mathrm{~min}$. Total protein was quantified in an aliquot of the supernatant with a Micro-BCA kit using a microplate spectrophotometer EPOCH (BioTek).

\section{Quantification of HSP70 protein levels}

HSP70 was measured in the gill tissue of each individual by enzyme-linked immunosorbent assay (ELISA), which was validated in previous assays by comparing ELISA results with immunoprobing of western blots from western blot analyses (using the antibodies described below), which showed only one band at the level of $70 \mathrm{kD}$ HSP. Total protein (30 $\mu \mathrm{g} \mathrm{ml} \mathrm{m}^{-1}$ ) was diluted in $0.05 \mathrm{M}$ carbonatebicarbonate buffer at $\mathrm{pH} 9.6$, and $50 \mu$ l of sample per well was incubated in an ELISA plate overnight at $4{ }^{\circ} \mathrm{C}$ with 3 blanks (containing buffer only). The plate was then washed twice with phosphatebuffered saline (PBS) $(200 \mu \mathrm{l}$ per well). Next, $200 \mu \mathrm{l}$ of blocking buffer (PBS $+5 \%$ skim milk) was added to each well and incubated for $2 \mathrm{~h}$. The wells were washed again with PBS. Subsequently, $100 \mu$ of the primary antibody-polyclonal mono-specific antiepitope that recognize the inducible and constitutive forms of HSP70 specific for Argopecten purpuratus, developed in immunized mice with a synthetic peptide epitope (Group of Immunological Markers on Aquatic Organisms, Catholic University of Valparaiso) - diluted 1:400 in blocking buffer $+0.05 \%$ Tween-20 was added to each well, and the plate was incubated overnight at $4^{\circ} \mathrm{C}$. The plate was then washed 4 times with PBS, incubated with goat antimouse IgG (Thermo Scientific) secondary antibody, diluted in blocking buffer $+0.05 \%$ Tween-20 for $2 \mathrm{~h}$ at $25^{\circ} \mathrm{C}$, and washed again 4 times with PBS. Next, $100 \mu \mathrm{l}$ of substrate solution (10 mg o-phenylenediamine dihydrochloride in $25 \mathrm{ml}$ of $0.05 \mathrm{M}$ citrate phosphate buffer) was added, followed by incubation of the plate for $30 \mathrm{~min}$ at $25^{\circ} \mathrm{C}$. Finally, the plate was read at $450 \mathrm{~nm}$ in a microplate spectrophotometer. The absorbance of the sample was corrected by the mean absorbance of the blanks. HSP70 levels were expressed relative to the respective protein level of the unstressed immature group.

\section{CS activity}

We homogenized the samples of gill tissue on ice ( $\mathrm{n}=7$ per reproductive status), in 10 volumes of $50 \mathrm{mM}$ imidazole-HCl, $2 \mathrm{mM}$ EDTA-Na $2,5 \mathrm{mM}$ EGTA, 1 mM dithiothreitol and $0.1 \%$ Triton X-100, $\mathrm{pH}$ 6.6. The homogenates were centrifuged at $4^{\circ} \mathrm{C}$ for $15 \mathrm{~min}$ at $600 \times g$. We measured enzyme activity at controlled room temperature $\left(20^{\circ} \mathrm{C}\right)$ using a UV/Vis spectrophotometer (Cary 50 Bio, Varian). Conditions for enzyme assays were adapted from conditions used by Brokordt et al. (2000a) for Chlamys islandica, as follows (all concentrations in $\mathrm{mmol} \mathrm{l}^{-1}$ ): TRIS-HCl 75 , oxaloacetate 0.3 (omitted for the control), DTNB 0.1 and acetyl CoA 0.2, pH 8.0. Enzyme activity was examined by following the absorbance changes at 
$412 \mathrm{~nm}$ to detect the transfer of sulphydryl groups from CoASH to DTNB. The extinction coefficient used for DTNB was $13.6 \mathrm{~cm}^{-1} \mu_{\mathrm{mol}}^{-1}$. All assays were run in duplicate and the specific activities are expressed in international units ( $\mu$ mol of substrate converted to product per minute) per gram of gill mass.

\section{Statistical analyses}

To evaluate the effect of reproductive stage on hsp70 mRNA levels and HSP70 abundance in A. purpuratus exposed to thermal and hypoxia stress factors, we performed 2-way ANOVAs for each stress factor. Model predictors were reproductive stage (with 3 levels: immature, mature and spawned) and presence/absence of the stressor (high temperature or hypoxia). To evaluate the effect of reproductive stage on CS enzyme activity, we performed a 1-way ANOVA. For both ANOVAs, normality of the dependent variable was tested using the Shapiro-Wilks test (SAS Institute 1999) and homogeneity of variances using Levene's test (Snedecor \& Cochran 1989) to verify that the data met model assumptions. A posteriori tests for specific differences were conducted via the multiple pairwise comparisons least-square means (Lenth \& Hervé 2015), with significance evaluated at $\mathrm{p} \leq 0.05$.

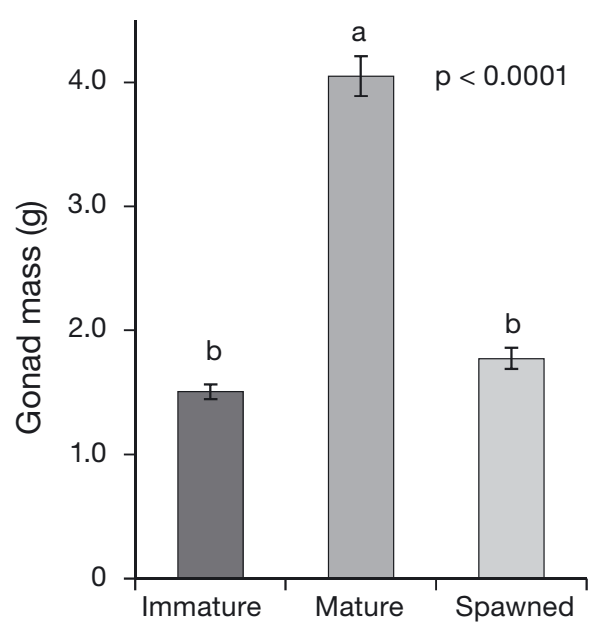

Fig. 1. Changes in gonad mass in Argopecten purpuratus scallops in 3 different reproductive stages (immature, mature and spawned). Immature and mature scallops were obtained from a cultured population. Spawning was induced in the laboratory. Values represent means $\pm \mathrm{SE}(n=60$ per reproductive stage). Means sharing the same letter are not significantly different $(\mathrm{p} \geq 0.05)$ from one another as indicated by a posteriori multiple comparisons (least-square means)

\section{RESULTS}

\section{Changes in gonad mass and metabolic capacity with reproductive status}

The mean gonad mass was approximately $170 \%$ greater in mature Argopecten purpuratus scallops than in immature scallops, indicating substantial reproductive investment (Fig. 1). After spawning, the mean gonad mass was similar to that of immature animals.

CS activity varied with $A$. purpuratus reproductive status (Fig. 2). This enzyme showed its highest levels in immature scallops, tended to decline with gonadal maturation, and attained its lowest level in spawned scallops (Fig. 2). CS activity was significantly different between immature and spawned scallops ( $\mathrm{p}=$ 0.044).

\section{Hsp70 mRNA levels and HSP70 abundance in scallops of different reproductive status following different stressors}

Hsp70 mRNA relative levels increased significantly after exposure to thermal stress in scallops with each of the different reproductive statuses (Table 1, Fig. 3). However, in immature scallops, this increase in $h s p 70$ mRNA levels was more than 2-fold higher than in mature and spawned scallops. Immature stressed

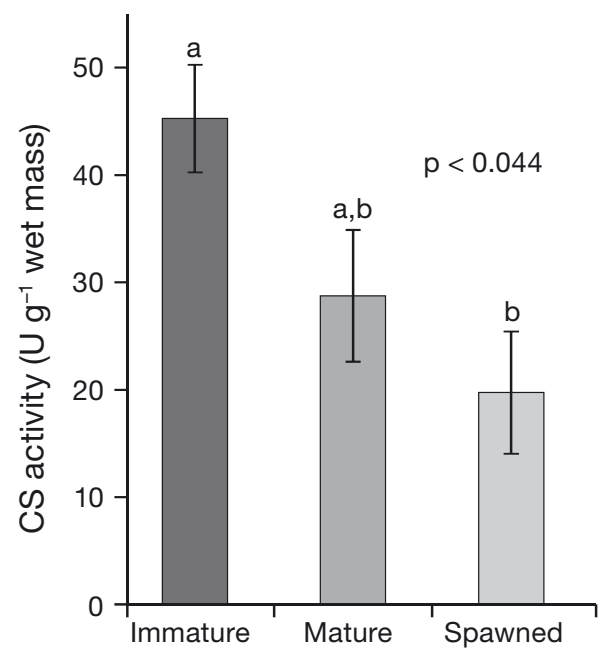

Fig. 2. Citrate synthase (CS) activities in gill tissue of Argopecten purpuratus scallops in 3 different reproductive stages (immature, mature and spawned) as an indicator of the tissue capacity for ATP generation via mitochondrial oxygen-dependent metabolism. Values represent means \pm SE $(n=7$ per reproductive stage). Means sharing the same letter are not significantly different $(\mathrm{p} \geq 0.05)$ from one another as indicated by a posteriori multiple comparisons (least-square means) 
Table 1. Results of 2-way ANOVAs comparing hsp70 gene transcription and protein induction levels between Argopecten purpuratus scallops with different reproductive status, exposed to stress by temperature or hypoxia. Reproductive status: immature, mature and spawned; temperature: $24^{\circ} \mathrm{C}$ (stress temperature) or $18^{\circ} \mathrm{C}$ (control temperature); oxygen: hypoxia ( 2.0-1.5 $\mathrm{mg} \mathrm{O}_{2} \mathrm{l}^{-1}$, stress) or normoxia ( 8.0 $\mathrm{mg} \mathrm{O}_{2} \mathrm{l}^{-1}$, control). For gene expression, $\mathrm{n}=5$ replicates per condition (each replicate includes 3 individuals' total RNA). For protein expression, $\mathrm{n}=12-14$ individuals per condition

\begin{tabular}{|lccc|}
\hline Source & df & $F$ & $p$ \\
\hline Hsp70 gene transcription & after & & \\
Model & 1 & 837 & 0.000000 \\
Reproductive status (RS) & 2 & 31.8 & 0.000000 \\
Stress level (SL) & 1 & 82.7 & 0.000000 \\
RS $\times$ SL & 2 & 14.1 & 0.000057 \\
Error & $\mathrm{b}$ & & \\
& & & \\
HSP70 protein levels after thermal stress & \\
Model & 1 & 466 & 0.000000 \\
RS & 2 & 8.31 & 0.000611 \\
SL & 1 & 2.09 & 0.152843 \\
RS $\times$ SL & 2 & 18.9 & 0.000000 \\
Error & 71 & & \\
HSP70 protein levels after hypoxia stress & \\
Model & 1 & 128 & 0.000000 \\
RS & 2 & 3.16 & 0.047551 \\
SL & 1 & 13.5 & 0.000433 \\
RS $\times$ SL & 2 & 6.55 & 0.002321 \\
Error & 83 & & \\
\hline
\end{tabular}

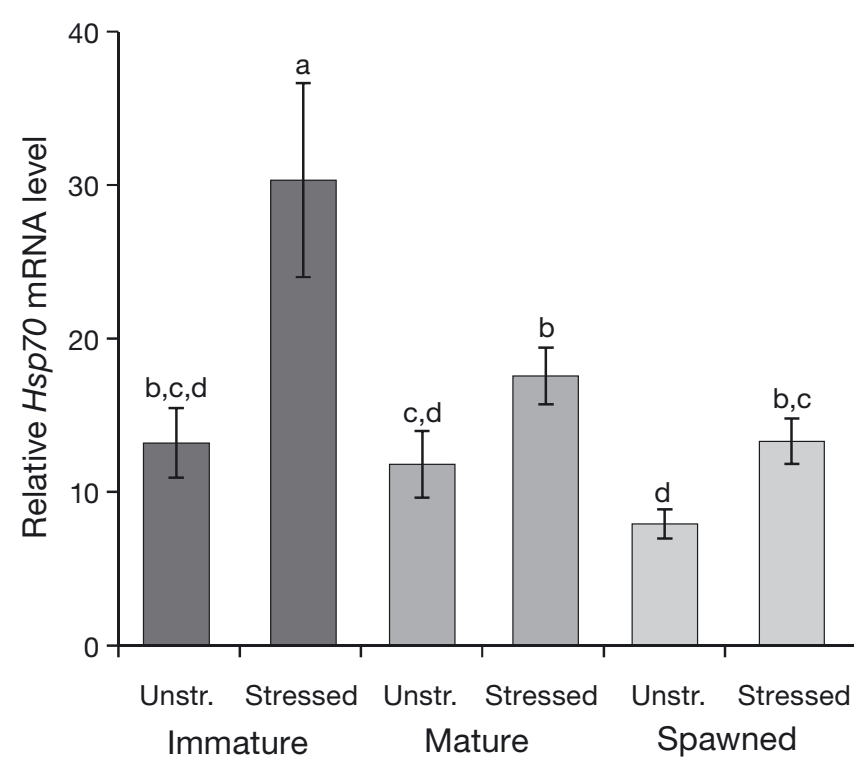

Fig. 3. Relative Hsp70 gene transcription (mRNA) levels measured in gill tissue of Argopecten purpuratus scallops exposed (stressed) and not exposed (unstressed, controls) to thermal stress in 3 different reproductive stages (immature, mature and spawned). Values represent means $\pm \mathrm{SE}(\mathrm{n}=5$ replicates per condition; each replicate includes 3 individuals' total RNA). Means sharing the same letter are not significantly different $(p \geq 0.05)$ from one another as indicated by a posteriori multiple comparisons (least-square means) scallops showed $130 \%$ more hsp 70 mRNA than unstressed scallops, whereas stressed mature individuals showed $49 \%$ and spawned scallops $65 \%$ more hsp 70 mRNA than unstressed scallops.

Following exposure to thermal or hypoxia stress, immature A. purpuratus had significantly higher HSP70 protein levels (1.5- and 2-fold higher, respectively) than non-stressed immature scallops (Table 1 , Fig. 4). However, following gonad maturation and spawning, there were not statistically significant differences ( $p>0.05)$ in the HSP70 levels between scallops exposed and not exposed to thermal or hypoxia stress. Spawned scallops exposed to thermal stress and hypoxia had slightly higher levels of HSP70 relative to control animals, but this difference was not significant (Table 1, Fig. 4).

\section{DISCUSSION}

Our results show that the capacity of mature and spawned Argopecten purpuratus to increase hsp70 mRNA and HSP70 levels following exposure to thermal and hypoxia stressors was markedly reduced relative to that of immature individuals. Interestingly, the reduction in HSP70 induction capacity after gonad maturation was similar for both stressors. In parallel to these reductions, we observed a decrease in the activity of the mitochondrial enzyme CS. CS is a key enzyme regulating the tricarboxylic acid cycle and thus the capacity for ATP generation via mitochondrial oxygen-dependent metabolism of cells and/or tissue (Storey 2004). Therefore, reduced hsp 70 mRNA and HSP70 levels following reproductive processes could reflect an energetic compromise between the production of these proteins and gametogenic activity.

In several scallop species, available energy becomes limited during reproduction, as revealed by the sharp decrease in energy reserves following gonadal maturation and spawning (Martínez 1991, Martínez et al. 2000, Brokordt \& Guderley 2004). In A. purpuratus from the same studied population, an approximately $50 \%$ decrease in adductor muscle carbohydrate stores has been observed following gonadal maturation, persisting until after spawning (K. Brokordt unpubl. data). We have also observed reductions in the quality and oxidative capacity of muscle mitochondria following gonadal maturation and spawning in Chlamys islandica scallops (Brokordt et al. 2000a). Decreased metabolic capacity of the anaerobic and aerobic metabolic pathways (through reduction of glycogen phosphorylase, pyru- 


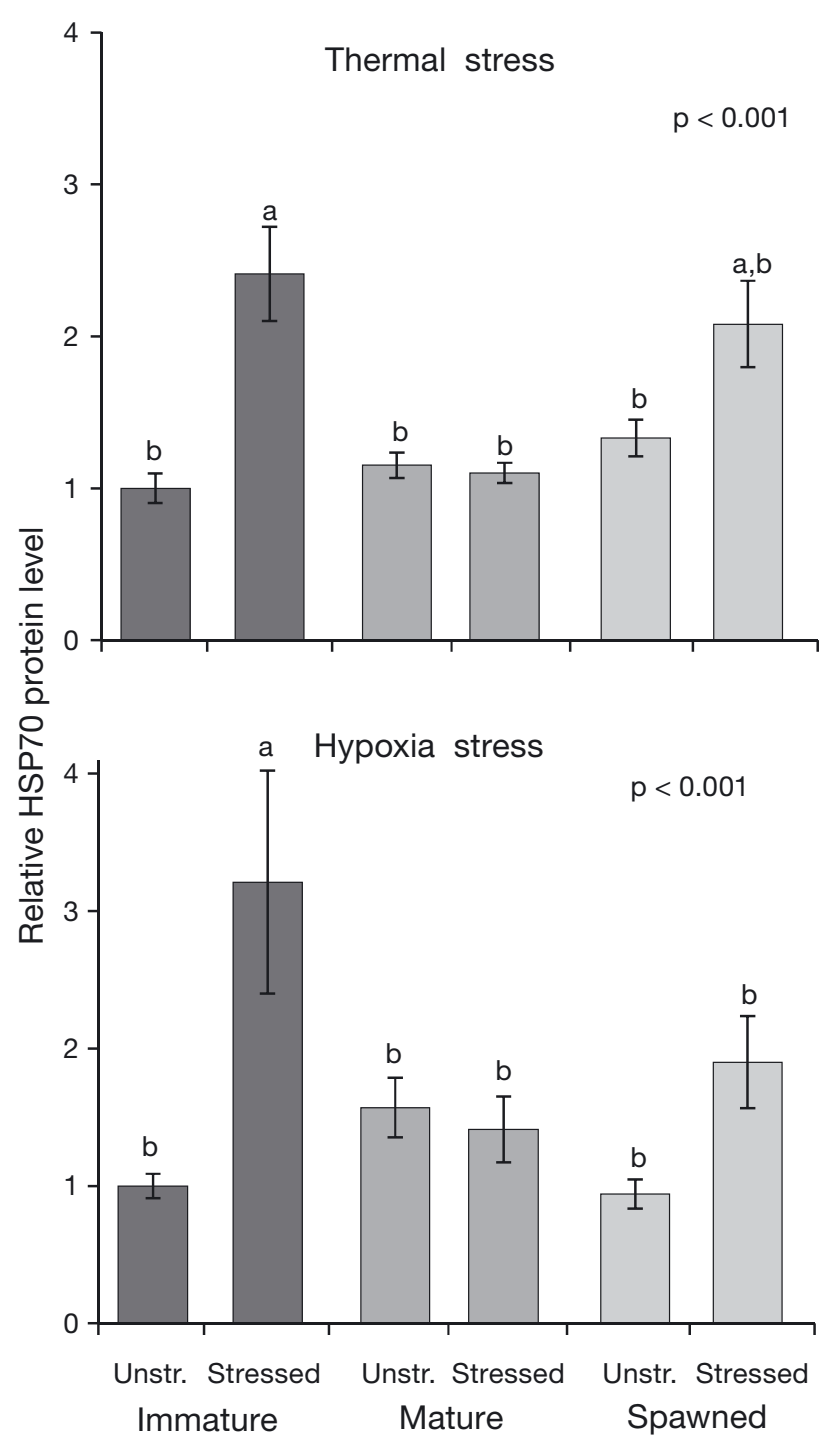

Fig. 4. Relative HSP70 protein levels measured in gill tissue of Argopecten purpuratus scallops exposed (stressed) and not exposed (unstressed, controls) to thermal and hypoxia stress in 3 different reproductive stages (immature, mature and spawned). Values represent means $\pm \mathrm{SE}$ ( $\mathrm{n}=15$ per condition). Means sharing the same letter are not significantly different $(\mathrm{p} \geq 0.05)$ from one another as indicated by a posteriori multiple comparisons (least-square means)

vate kinase, phosphofructokinase, octopine dehydrogenase and CS) following gonadal maturation and spawning has also been observed in C. islandica (Brokordt et al. 2000a) and Euvola ziczac (Brokordt et al. 2000b). Moreover, maintenance metabolic requirements were higher after gonad maturation in Placopecten magellanicus (Kraffe et al. 2008). Therefore, the declines in energy availability and metabolic capacity along with the increased metabolic demands of gonadal maturation, which last until spawning, could limit the amount of energy available for the gene transcription and protein synthesis of HSP70, explaining our results.

The actual energetic cost of mounting a cellular stress response through HSPs is poorly understood. Stress proteins play an important role in energydependent processes, such as protein translocation into cellular organelles (Beckmann et al. 1990) and the binding and release of denatured proteins and short peptides to HSP70 (McKay et al. 1994, Mayer \& Bukau 2005). Recently, it was observed that under in vitro conditions, one Hsp70 molecule consumed 5 ATPs to unfold a single misfolded protein into an intermediate that, upon chaperone dissociation, spontaneously refolded to its native state (Sharma et al. 2010). Thus, ATP is considered indispensable for correct HSP70 functioning (Morimoto 1993, Currie et al. 1999). Gene transcription and translation are also energetically expensive. Hsp70 mRNA transcription appears to be energetically limited in the red blood cells of rainbow trout subjected to extreme energetic stress, such as that occurring during combined heat shock and metabolic inhibition (i.e. decreased ATP by $79 \%$; Currie et al. 1999). Although the exact amount of ATP necessary for HSP protein synthesis is unknown, the entirety of protein synthesis is estimated to cost between 25 and $40 \%$ (in mussels and fish, respectively) of an organism's total oxidative metabolism (Hawkins 1985, Lyndon et al. 1992). A study evaluating the cost of maintaining high HSP levels upon exposure to long-term stress in the trout Oncorhynchus mykiss found that chronic stress (i.e. elevated HSP72 and HSP89) decreased metabolic condition (i.e. reduced muscle phosphocreatine, ATP and glycogen) (Viant et al. 2003). Similarly, individual Drosophila melanogaster that express additional copies of the hsp70 gene increase their metabolic rate by as much as $35 \%$ following exposure to heat stress (Hoekstra \& Montooth 2013). We observed different effects of the reproduction on the $h s p 70$ mRNA transcription and HSP70 protein levels in scallops exposed to thermal stress. After gonad maturation and spawning, hsp70 mRNA significantly increased (but less than before gonad maturation) in stressed scallops; however, there were no such increases in protein level in the same individuals. Although post-transcriptional regulation cannot be dismissed, these differences may reflect how the energetic restriction affected each of these processes. Given that we measured the expression of only one form of HSP70, and we cannot discard the potential existence of other forms of HSP70 in A. purpuratus, as have been reported for other bivalve species (Zhang et al. 2012), we may have evaluated only part 
of the response due to HSP70. Therefore, the effect of the energetic restriction may be even higher than observed in this study. Our results and the previous examples show that HSP synthesis and activity are energetically costly; however, the processes of degrading a misfolded protein and re-synthesizing another cost one thousand times more (Sharma et al. 2010). Therefore, this cellular stress response is considered a key physiological adaptation (Sharma et al. 2010, Morris et al. 2013).

HSP70 levels have traditionally been used as biomarkers of stress; i.e. the result of individuals attempting to cope with the damage caused by environmental assaults (Sørensen 2010, Morris et al. 2013). However, considering the energetic cost of this cellular response, variation in HSP70 levels among individuals exposed to the same stressor could indicate variation in the capacity to mount this cellular stress response (Sørensen 2010). This latter approach, i.e. HSP70-induced levels as an indicator of stress response capacity, although suggested in the literature (Sørensen 2010), is supported by almost no empirical evidence. However, a study in 2 land snails has shown a negative correlation between the endogenous HSP70 isoform levels in foot tissue and albumen gland mass (indicative of reproductive maturation) (Mizrahi et al. 2011). These authors indicate that reduced levels of HSP70 isoforms, preceding egg laying, may reduce the snail's ability to cope with external stress (Mizrahi et al. 2011). Nevertheless, this study did not evaluate the changes in HSP induction in these snails upon exposure to stress. Additionally, in a recent study in the intertidal marine snail Concholepas concholepas, we found that individuals in poor energetic condition showed reduced HSP70 induction in response to hypoxia and/ or heat and cold thermal stress relative to individuals in good energetic condition (Jeno \& Brokordt 2014). Finally, in Crassostrea gigas oysters, levels of the 72 and $69 \mathrm{kDa}$ HSPs were lower in post-spawning than in pre-spawning individuals after being stimulated by heat shock, indicating that spawning reduced HSP synthesis (Li et al. 2007). Also, the post-spawning oysters had depleted glycogen stores and reduced adenylate energy charge compared with pre-spawning individuals, indicative of lower energy availability for metabolic activity ( $\mathrm{Li}$ et al. 2007). These studies and the present study support the 'capacity approach' for observed HSP levels.

In life-history evolution, trade-offs represent the cost paid in the currency of fitness (i.e. the ability to produce fertile progeny), because an improvement in a fitness-related trait is associated with a detrimental change in another fitness-associated trait (Reznick 1985, Stearns 1989). One prominent trade-off is the cost of reproduction, in which current reproductive parental investment reduces parental longevity (e.g. reducing survival probability) or future reproductive capacity (Reznick 1985). Several energetic trade-offs between fitness-associated traits have been observed in mollusks. For example, in the cockle Cerastoderma edule, gonadal maturation has been associated with a decrease in the amount of energy available for growth (Iglesias \& Navarro 1991), and for the scallops C. islandica (Brokordt et al. 2000a,b), A. purpuratus (Brokordt et al. 2006, Pérez et al. 2009) and Placopecten magellanicus (Kraffe et al. 2008), it is associated with a decrease in metabolic support for the escape response. In $D$. melanogaster and the abalone Haliotis discus hannai, induction of HSP70 has been associated with fitness (Krebs \& Feder 1997, Sørensen et al. 2003, Cheng et al. 2006), because it increases tolerance to physiological stressors and may be critical for survival in some circumstances. Our results suggest that the observed reduction in HSP70 synthesis capacity following reproductive investment is a reproductive cost, as the decreased stress response capacity may limit future survival probability, and may reflect the existence of an evolutionary trade-off between these traits.

Energetic trade-offs between reproduction and other physiological functions can be sufficiently strong that mortality rates increase during postmaturation and spawning processes (Perdue et al. 1981, Barber \& Blake 1983, Rocha et al. 2001). Mass mortality after maturation and spawning has been reported in several species of bivalves (Perdue et al. 1981, Barber \& Blake 1983) and often coincides with strong environmental change (Cheney et al. 2000, Tomaru et al. 2001, Xiao et al. 2005). Argopecten purpuratus beds and artificial culture systems typically occur in bays near upwelling zones and are therefore exposed to fluctuations in dissolved oxygen levels. Periods of decreased oxygen levels can persist for several days during the spring-summer season (Zhang et al. 2010, CEAZA Oceanographic Monitoring System unpubl. data). Similarly, increased mortality rates of mature $A$. purpuratus have been observed in cultures in northern Chile (Bahía Inglesa and Tongoy Bay; Camanchaca Ostimar and INVERTEC growing companies, unpubl. data) and in natural beds in Peru (Cabello et al. 2002), most likely in association with periods of hypoxia. During the spring-summer season, scallops are not only more subject to hypoxia $\left(<2.0 \mathrm{mg} \mathrm{O}_{2} \mathrm{l}^{-1}\right)$, but have also reached gonadal maturation and are initiating spawning. In culture, these 
processes are compounded with increased manipulation (e.g. sorting and cleaning of culture systems). Increased energy demands resulting from reproduction and environmental stressors, in combination with reduced HSP70 synthesis capacity, could partially explain the increase in mortality rates observed in natural and cultured $A$. purpuratus populations.

In conclusion, our results suggest that reproductive investment may reduce the stress response capacity of A. purpuratus, such that mature and spawned scallops should be more vulnerable to environmental stress effects than immature individuals. The similar observed effects of the 2 different types of stressor (hypoxia and heat stress, both of which occur frequently in natural and cultured scallops populations) suggest a consistent pattern of response in this species.

Acknowledgements. We are grateful to Felipe Campos and Igor Vidal for their help with animal manipulation during the experiments. This study was supported by FONDECYT 3110101 funding to H.P. and K.B.

\section{LITERATURE CITED}

Barber BJ, Blake NJ (1983) Growth and reproduction of the bay scallop, Argopecten irradians (Lamarck) at its southern distributional limit. J Exp Mar Biol Ecol 66:247-256

$>$ Beckmann RP, Welch WJ, Mizzen LA (1990) Interaction of HSP70 with newly synthesized proteins: implication for protein folding and assembly. Science 248:850-854

Brokordt K, Guderley H (2004) Energetic requirements during gonad maturation and spawning in scallops: sex differences in Chlamys islandica (Muller 1776). J Shellfish Res 23:25-32

Brokordt KB, Himmelman JH, Guderley H (2000a) Effect of reproduction on escape responses and muscle metabolic in the scallop Chlamys islandica Muller 1776. J Exp Mar Biol Ecol 251:205-225

Brokordt KB, Himmelman JH, Nusetti OA, Guderley H (2000b) Reproductive investment reduces recuperation from exhaustive escape activity in the tropical scallop Euvola ziczac. Mar Biol 137:857-865

Brokordt K, Guderley H, Guay M, Gaymer C, Himmelman J (2003) Sex differences investment: maternal care reduces escape responses capacity in the whelk Buccinum undatum. J Exp Mar Biol Ecol 291:161-180

Brokordt K, Fernandez M, Gaymer C (2006) Domestication reduces the capacity to escape from predators. J Exp Mar Biol Ecol 329:11-19

Cabello R, Tam J, Jacinto ME (2002) Procesos naturales y antropogénicos asociados al evento de mortalidad de conchas de abanico ocurrido en la bahía de Paracas (Pisco, Perú) en junio del 2000. Rev Peruana Biol 9:49-65

Calderwood SK (2007) Cell stress proteins. In: Zouhair Atassi M (ed) Protein reviews, Vol 7. Springer, New York, NY

> Cantillanez M, Avendaño M, Thouzeau G, Le Pennec M (2005) Reproductive cycle of Argopecten purpuratus (Bivalvia: Pectinidae) in La Rinconada marine reserve
(Antofagasta, Chile): response to environmental effects of El Niño and La Niña. Aquaculture 246:181-195

Cheney DP, MacDonald BF, Elston RA (2000) Summer mortality of Pacific oysters, Crassostrea gigas (Thunberg): initial findings on multiple environmental stressors in Puget Sound, Washington, 1998. J Shellfish Res 19: 353-359

Cheng P, Liu X, Zhang G, Deng Y (2006) Heat-shock protein 70 gene expression in four hatchery pacific abalone Haliotis discus hannai Ino populations using for markerassisted selection. Aquac Res 37:1290-1296

Currie S, Tufts BL, Moyes CD (1999) Influence of bioenergetic stress on heat shock protein gene expression in nucleated red blood cells of fish. Am J Physiol 276: R990-R996

Disalvo L, Alarcon E, Martínez E, Uribe E (1984) Progress in mass culture of Chlamys (Argopecten) purpurata Lamarck (1819) with notes of its natural history. Rev Chil Hist Nat $57: 35-45$

Feder ME, Hofmann GE (1999) Heat-shock proteins, molecular chaperones, and the stress response. Annu Rev Physiol 61:243-282

- Frydman J, Nimmesgern E, Ohtsuka K, Hartl FU (1994) Folding of nascent polypeptide chains in a high molecular mass assembly with molecular chaperones. Nature 370:111-117

- Hartl FU, Hayer-Hartl M (2002) Molecular chaperones in the cytosol: from nascent chain to folded protein. Science 295:1852-1858

> Hawkins AJS (1985) Relationships between the synthesis and breakdown of protein, dietary absorption and turnovers of nitrogen and carbon in the blue mussel, Mytilus edulis. Oecologia 66:42-49

Hoekstra LA, Montooth KL (2013) Inducing extra copies of the Hsp70 gene in Drosophila melanogaster increases energetic demand. BMC Evol Biol 13:68

> Hofmann G, Somero G (1995) Evidence for protein damage at environmental temperatures: seasonal changes in levels of ubiquitin conjugates and hsp70 in the intertidal mussel Mytilus trossulus. J Exp Biol 198:1509-1518

Iglesias JIP, Navarro E (1991) Energetics of growth and reproduction in cockles (Cerastoderma edule): seasonal and age-dependent variations. Mar Biol 111:359-368

Jeno K, Brokordt K (2014) Nutritional status affects the capacity of the snail Concholepas concholepas to synthesize Hsp70 when exposed to stressors associated with tidal regimes in the intertidal zone. Mar Biol 161: 1039-1049

Kraffe E, Tremblay R, Belvin S, LeCoz J, Marty Y, Guderley H (2008) Effect of reproduction on escape responses, metabolic rates and muscle mitochondrial properties in the scallop Placopecten magellanicus. Mar Biol 156:25-38

$>$ Krebs RA, Feder ME (1997) Deleterious consequences of Hsp70 overexpression in Drosophila melanogaster larvae. Cell Stress Chaperones 2:60-71

Lenth RV, Hervé M (2015) Least-squares means: R package version 2.14. http://cran.r-project.org

Li Y, Qin JG, Abbott C, Li X, Bekendorff K (2007) Synergistic impacts of heat shock and spawning on the physiology and immune health of Crassostrea gigas: an explanation for summer mortality in Pacific oysters. Am J Physiol 293: R2353-R2362

> Livak KJ, Schmittgen TD (2001) Analysis of relative gene expression data using real-time quantitative PCR and the $2^{-\Delta \Delta C_{\mathrm{T}}}$ method. Methods 25:402-408 
Lodeiros C, Maeda-Martinez AN, Freites L, Uribe E, LluchCota DB, Sicard MT (2001) Ecophysiology of scallops from Iberoamerica. In: Maeda-Martínez AN (ed) Los moluscos pectinidos de Iberoamerica: ciencia y acuicultura. Editorial Limusa, Mexico City, p 77-88

Lyndon AR, Houlihan DF, Hall SJ (1992) The effect of shortterm fasting and a single meal on protein synthesis and oxygen consumption in cod, Gadus morhua. J Comp Physiol B 162:209-215

Martínez G (1991) Seasonal variation in biochemical composition of three size classes of the Chilean scallop Argopecten purpuratus Lamarck, 1819. Veliger 34:335-343

Martínez G, Mettifogo L (1998) Mobilization of energy from adductor muscle for gametogenesis of the escallops, Argopecten purpuratus Lamarck. J Shellfish Res 17:113-116

Martínez G, Pérez H (2003) Effect of different temperature regimes on reproductive conditioning in the scallop Argopecten purpuratus. Aquaculture 228:153-167

Martínez G, Brokordt K, Aguilera C, Soto V, Guderley H (2000) Effect of diet and temperature upon muscle metabolic capacities and biochemical composition of gonad and muscle in Argopecten purpuratus Lamarck 1819. J Exp Mar Biol Ecol 247:29-49

Mayer MP, Bukau B (2005) Hsp70 chaperones: Cellular functions and molecular mechanisms. Cell Mol Life Sci 62:670-684

McKay DB, Wilbanks SM, Flaherty KM, Ha JH, O'Brien MC, Shirvanee LL (1994) Stress-70 proteins and their interaction with nucleotides. In: Morimoto RI, Tissieres A, Georgopoulos C (eds) The biology of heat shock proteins and molecular chaperones. Cold Spring Harbor Laboratory Press, Cold Spring Harbor, New York, NY, p 153-177

> Mizrahi T, Heller J, Goldberg S, Arad Z (2011) Heat shock protein expression in relation to reproductive cycle in land snails: implication for survival. Comp Biochem Physiol A 160:149-155

Morimoto RI (1993) Cells in stress: transcriptional activation of heat shock genes. Science 259:1409-1410

Morris JP, Thatje S, Hauton C (2013) The use of stress-70 proteins in physiology: a re-appraisal. Mol Ecol 22: 1494-1502

Parsell DA, Lindquist S (1993) The function of heat-shock proteins in stress tolerance: degradation and reactivation of damaged proteins. Annu Rev Genet 27:437-496

Perdue A, Beattie JH, Chew KK (1981) Some relationships between gametogenic cycle and summer mortality phenomenon in the Pacific oyster (Crassostrea gigas) in Washington state. J Shellfish Res 1:9-16

Pérez HM, Brokordt K, Martínez G, Guderley H (2009) Effect of spawning on force production during escape responses of the scallop Argopecten purpuratus. Mar Biol 156:1585-1593

Reznick D (1985) Costs of reproduction: an evaluation of the empirical evidence. Oikos 44:257-267

Rocha F, Guerra A, Gonzalez AF (2001) A review of reproductive strategies in cephalopods. Biol Rev Camb Philos

Editorial responsibility: Peter Beninger, Nantes, France
Soc 76:291-304

Samain JF, Dégremont L, Solechnik P, Haure J and others (2007) Genetically based resistance to summer mortality in the Pacific oyster (Crassostrea gigas) and its relationship with physiological, immunological characteristics and infection processes. Aquaculture 268:227-243

SAS Institute (1999) The SAS system for Windows, version 8.0. SAS Institute, Cary, NC

Sastry AN (1968) The relationships among food, temperature and gonad development of the bay scallop Aequipecten irradians Lamarck. Physiol Zool 41:44-53

> Sharma S, Singh R, Kaur M, Kaur G (2010) Late-onset dietary restriction compensates for age-related increase in oxidative stress and alterations of HSP 70 and synapsin1 protein levels in male Wistar rats. Biogerontology 11:197-209

Snedecor GW, Cochran WG (1989) Statistical methods, 8th edn. Iowa State University Press, Ames, IA

Somero GN (2002) Thermal physiology and vertical zonation of intertidal animals: optima, limits, and costs of living. Integr Comp Biol 42:780-789

Sørensen JG (2010) Application of heat shock protein expression for detecting natural adaptation and exposure to stress in natural populations. Curr Zool 56:703-713

Sørensen JG, Kristensen TN, Loeschcke V (2003) The evolutionary and ecological role of heat shock proteins. Ecol Lett 6:1025-1037

Stearns SC (1989) Trade-offs in life-history evolution. Funct Ecol 3:259-268

Storey KB (2004) Functional metabolism: regulation and adaptation. Wiley-Liss, Hoboken, NJ

- Tomaru Y, Kawabata Z, Nakano S (2001) Mass mortality of the Japanese pearl oyster Pinctada fucata martensii in relation to water temperature, chlorophyll $a$ and phytoplankton composition. Dis Aquat Org 44:61-68

- Tremblay R, Myrand B, Sevigny JM, Blier P, Guderley H (1998) Bioenergetic and genetic parameters in relation to susceptibility of blue mussels, Mytilus edulis (L.) to summer mortality. J Exp Mar Biol Ecol 221:27-58

> Viant MR, Werner I, Rosenblum ES, Gantner AS, Tjeerdema RS, Johnson ML (2003) Correlation between heat-shock protein induction and reduced metabolic condition in juvenile steelhead trout (Oncorhynchus mykiss) chronically exposed to elevated temperature. Fish Physiol Biochem 29:159-171

Xiao J, Ford SE, Yang H, Zhang G, Zhang F, Guo X (2005) Studies on mass summer mortality of cultured zhikong scallops (Chlamys farreri Jones et Preston) in China. Aquaculture 250:602-615

- Zhang J, Gilbert D, Gooday AJ, Levin L and others (2010) Natural and human-induced hypoxia and consequences for coastal areas: synthesis and future development. Biogeosciences 7:1443-1467

Zhang G, Fang X, Guo X, Li L and others (2012) The oyster genome reveals stress adaptation and complexity of shell formation. Nature 490:49-54

Submitted: August 13, 2014; Accepted: February 19, 2015

Proofs received from author(s): March 26, 2015 